\title{
ON THE ORIGIN OF THE WEST INDIAN FAUNA
}

BY

\author{
R. F. SCHARFF.
}

Many zoologists have attempted to solve this problem which is a complicated one. In one respect the views of almost all agree. It is in the belief that the West Indian islands must have undergone profound alterations in configuration during the past. It is thought that at one time they must all have formed a continuous land surface. At another time, as has been suggested, some of them were attached to a neighbouring mainland of which they formed large promontories. At still another period of their history some at any rate of the islands must have been smaller than they are now. Many botanists and geologists agree with these theories, and these views imply that the animals and plants now living on the Antilles have mainly wandered to the islands from the Continent at a time when the latter were connected with one another.

One of the strongest arguments in favour of the former land connection of an island with the neighbouring Continent is the occurrence on the island of such mammals as could not have been transported there by human agency. As regards the Antilles, objections have been raised to this argument on account of the paucity of the mammalian fauna on the islands as compared with the wealth of the mammals on the mainland. Within recent years however, these islands have yielded quite a number of fossil types of mammals thus greatly strengthening the opinion that the West Indies owe their fauna to the fact of their having once been joined to the mainland. Nevertheless as some authorities still maintain that the Antilles have never been connected by land with the adjoining Continents - at any rate not in Tertiary times - it may be of interest once more to review this most important aspect of the Antillean problem.

I shall elucidate the main evidence for the widespread belief that the West Indian fauna and flora have reached the islands mainly during a continental, land connection, and endeavour to show how. we can most readily explain the past history of the islands from a study of their animals and plants. Evidence will also be adduced on purely paleontological and geological grounds as to the probable sequence of events in the history of the Antillean region.

Although von HumBold long ago suggested that the Antilles represented the drowned remnants of a larger land area, Prof. Suess (46) was the first to demonstrate unmistakably the intimate structural relationship between these islands and the Central and South American mountain systems. He pointed out that the two mountain chains of Yucatan and Guatemala, trending in a north easterly direction, could only be regarded as the western continuations of the mountain systems of the Greater Antilles. A structural relationship of the West Indies with the mountains of Venezuela seems also indicated. From the character and relations of the Cuban rocks, Dr. Frazer (21) deduced even a physical continuity with the Archaean system of the Northern Continent, although this view has not met with any support in recent years. HILL (27) maintains that the cristalline rocks referred to by FRAZER are not Archaean but Cretaceous and post-Eocene. But the terrestrial debris constituting the Eocene deposits throughout the islands are a testimony of the pre-existence of extensive Cretaceous land areas. A profound subsidence during late Eócene and early Oligocene, according to Dr. HILl's views, submerged all except the loftiest pinnacles of the islands, and this was succeeded by a tremendous uplift in the 
late Oligocene or Miocene connecting the islands with one another without however establishing land connections with the North and South American Continents. Later on, he says, in Miocene or Pliocene times, the Antilles were submerged to approximately their present outlines which they have retained ever since.

In 1864 the astounding discovery was made, in Cuba, of the bones of several large extinct mammals, and this appeared to DE CASTRO (17) a proof of Cuba having been united by land with the American Continent in post-Tertiary times. A mandible of the large ground Sloth Megalonyx from Cuba was subsequently exhibited in Paris and described by Pomel. A few years later the bones and teeth of a large rodent from the island of Anquilla were shown by Prof. Cope (15) at a meeting of the Philadelphia Academy. Commenting on this remarkable discovery he expressed himself satisfied that the Caribbean Continent could not have been submerged prior to the post-Pliocene epoch, and that a wide strait separated it from the comparatively remote shores of North America. During a later exploration of the caves of Anquilla, Prof. COPE (16) unearthed eleven species of fossil vertebrates, several of them being of large size.

Until recent years no further discoveries of fossil terrestrial vertebrates were made in the West Indies. But in 1911 Dr. Montane met with the teeth of a monkey associated with human remains in a cave in Cuba. Mr. MiLler (36) has shown since that there are reasons for believing that the presence of this monkey in Cuba is due to the agency of Man.

In 1916 Dr. J. A. AlLEN (3) described a new genus of rodent whose remains, accompanied with human remains were found in a cave in the island of Porto Rico. It was about the size of a small rabbit and probably survived on the island until quite recently. Further researches at a lower depth in the same cave yielded bones of a new genus of sloth (Acratocnus) without any apparent affinity with the Cuban form, and two new genera of hystricomorph rodents. When we consider that no land mammals other than bats had hitherto been recorded from Porto Rico, this discovery augured well and encouraged further efforts. These have led to excellent results, for we have now become acquainted with an extinct insectivore (Nesophontes) of a very. primitive type. A certain degree of relationship with Centetes and Solenodon has been established, but Nesophontes is even more primitive than these two living Antillean genera, and as Mr. ANTHONy remarks, it is such a type as one might expect to find in Eocene deposits. Altogether five different kinds of rodents (6) were brought to light as well as two species of sloths. The latter exhibit relationship with the more primitive South American Megalonichidae. Whereas Mr. ANTHONY (7), who is responsible for these discoveries, is convinced that the West Indian islands at some period during the Tertiary Era were connected with one another and with Central or South America, he does not think this hypothesis has been established beyond all reasonable doubt. The Kitchen middens of Santo Domingo (Haiti) and Cuba have also yielded some interesting mammalian remains which enabled Mr. MILLER (35) to record the Porto Rican rodent Isobolodon for Haiti and two new genera of Spiny-rats (Protomys and Boromys) for Cuba. The author suggests that the hystricine rodents indicate a direct descent from a South American Miocene stock. Several new species of fossil insectivores and rodents have recently been described from Cuba and Jamaica (8 and 9).

Another line of argument to prove that the existing West Indian Islands are the remains of a large land mass is based on the nature and depth of the Caribbean sea. A series of dredging and sounding operations were carried out in that region, with the result that Prof. AGASsiz (1) was enabled to trace the outlines of the old South American Continent as he thought with tolerable accuracy. $\mathrm{He}$ maintained that Jamaica was only the northern spit of a large promontory. which once extended towards Haiti from the mainland of Central America. Another great mass of land projected northward from the coast of Venezuela. The Caribbean Sea was a gulf of the Pacific, and only communicated with the Atlantic by several narrow straits. No opinion is vouchsafed by AGAssiz as to the time when those geographical conditions prevailed, but Dr. SPENCER (45) who founded his speculations largely on the submerged system of drainage valleys contends that the latter supplies data for calculating the amount of elevation of the region in Pliocene and Pleistocene times. The extent of the changes in land and water suggested by SPENCER has not been confirmed by later observers, and it seems doubtful even if many of the depressions on the floor of the Caribbean Sea really represent submerged drainage valleys. 
The study of the marine fauna, both fossil and recent, of the West Indian region had led to a good many speculations regarding the past geography of that area. Thus GuPPY (25) pleaded for a Caribbean Continent on the strength of his researches on the fossil mollusca. But as he places this Continent right out in the Atlantic, his views (26) do not come directly within the scope of this paper. From a study of the fossil West Indian corals, Prof. GREgory (23) concluded that the Caribbean Sea in early Tertiary times was a gulf of the Pacific. The waterway across Central America must have been closed early in the Miocene, possibly even at the end of the Oligocene Period. He argues that North and South America may have been connected by land along the chain of the Windward Islands, Cuba, the Bahamas, and Florida, but he seems more positive about Cuba having once been joined to Yucatan and Florida.

In a series of scholarly essays Dr. VAUGHAN based his conclusions partly on geological grounds and partly on the distribution of fossil and corals. The first of these essays on the Floridean Plateau (47) is of interest in connection with the present enquiries as the author's researches do not lend any support to the theory that North and South America were connected by land across Florida and the Lesser Antilles. It is also of importance to note that on paleontological grounds Dr. Vaughan (48) holds that there was a communication between the Caribbean Sea and the Pacific in the Panama Canal zone during the middle and upper Oligocene. In a summary on the past geography of the whole Antillean area Dr. VAughan expresses the opinion that the major tectonic trends of both Cuba and Jamaica date back to late Palaeozoic times, that part of Cuba was above sea-level in the Mesozoic Era, and may possibly have been joined to the south-eastern United States. During the Upper Cretaceous extensive submergences occurred throughout the West Indies and Central America. At the commencement of the Tertiary Era the Antilles were raised above sea-level, whereas in later Eocene as well as in middle and upper Oligocene the islands were again submerged and interoceanic connection took place across Central America. The upper Miocene was a period of emergence. Although the junction of the two oceans across Central America appears then to have terminated, Dr. VAughan (49) suggests that even at that time interoceanic connection may have persisted at some places, possibly at the isthmus of Tehuantepec. The West Indian islands as we know them were probably produced by block-faulting during the Pliocene Period.

The existing terrestrial flora and fauna have likewise been utilised in the attempt to solve the problem of the origin of the Antilles.

Plant dispersal especially as regards the tropics has recently been very ably discussed by Mr. H. B. Guppy (24) who dwells on the importance of the buoyant quality of the seed and fruit. But as far as has been ascertained experimentally, buoyancy is not frequently met with in seeds (41). Transport of seeds by wind must not be lost sight of, and it ought to play an important part in the region under discussion. As a matter of fact it seems that comparatively fews kinds of seeds can be carried any distance by wind even if it should be exceptionally strong. The action of wind in plant dispersal has been critically discussed by PRAEGER (42) who demonstrated the amount of efficiency of various kinds of European seeds for transport by wind. All other accidental modes of transport are well known to botanists and have been carefully considered in coming to a conclusion as to the origin of any particular flora. Baron EgGers (18) for example in describing the origin of the floras of the island of St. Croix and the Virgin islands, rejected the theory of sea-transport by the various agencies. He believed that few of the plants found on the islands possess the faculty of crossing salt water. The great number of species common to all the islands and the circumstance that most of them are in no respect better adapted for occasional conveyance than the plants that are peculiar to the islands, point to a former land connection with the Continent. ENGLER's views (20) coincided with those expressed by EGGER and he emphasised that the endemic flora must be extremely ancient.

The invertebrate fauna of the West Indies has as yet been inadequately investigated. We are scarcely acquainted with the great class of insects except such groups as the beetles, butterflies and moths. Even among the land and freshwater mollusks which have been more diligently searched for than almost any other group, a good many gaps still remain for future workers. Still enough has been done to permit us to form a fairly sound judgment as to the origin of the fauna. Of all the insects one would imagine the flies (Diptera) to be most easily conveyed by adventitious means of transport 
such as drift vegetation and winds; and indeed as far as Jamaica is concerned, they show a distinct relationship with the United States (29). But since no other group of invertebrates exhibits a similar relationship, we must assume that their origin differs from that of the flies.

Certain freshwater animals probably furnish better clues as to the problem of former changes of land and water than almost any others. The presence for instance in Cuban rivers of a crayfish (Cambarus cubensis) points to a former continental union of $\mathrm{Cuba}$, and this land connection must have been sufficiently wide to have carried an extensive river system. Now the Cuban crayfish, as ORTMANN (38) has pointed out, belongs to a group of Cambarus which has its centre of distribution in South Western North America, probably in Mexico. The genus being a very ancient one, Cuba must have been connected by land with Mexico, in early Tertiary times, possibly through Guatemala. The occurrence in Cuba, Haiti, Porto Rico and Santa Cruz island of freshwater crabs (37) may be cited in support of the same view. The six species found in these islands all belong to the genus Epilobocera which is pecullar to the Greater Antilles. The presence of this freshwater crab is in all likelihood due to an ancient invasion from Central America. A much more recent one of the allied genus Pseudothelphusa reached only Cuba and Haiti, but the same genus advanced evidently from Venezuela to Trinidad, St. Lucia, Martinique, Dominica and Guadeloupe, implying a land connection between these islands and the mainland of South America in recent geological times.

The fishes may possibly be of less importance in our enquiries since it is permissible to argue that their eggs could have been conveyed to distant islands by water birds. Yet the presence in Cuba of the ancient genus Lepisosteus is significant. Prof. EJgenmann (19) is of opinion that the freshwater genera Symbranchus, Heros, Lepisosteus, and Agonostoma probably reached Cuba from Mexico by way of Yucatan, and he implied that they spread by means of a land connection.

An apparently insignificant freshwater snail (Hemisinus) living in Cuba is of some zoogeographical interest. Hemisinus (12) and related genera are river snails. They do not inhabit intermittent streams, ponds or lakes, and are quite unknown in brackish water. Their egg capsules are not gelatinous or likely to adhere to the feet of freshwater fowl, as they are firmly fixed to stones and other objects. The Cuban and Jamaican species are apparently traceable to a South American stock, but the related species of Pachycheilus occurring in the same islands have probably come from Central America. We must not forget also that two species of the freshwater bivalve Unio showing relationship with Central American forms occur in Cuban rivers.

Dr. SIMPSON (44) who has had a good deal of practical experience of all the occasional modes of conveyance among mollusks, especially in the West Indies, tells us that the hollow stems of dead bamboos are a favorite retreat for many species of terrestrial and arboreal snails. Describing the floating rafts which are frequently carried out to sea with their living cargo he remarks "I have seen such rafts and nothing could be more admirably contrived for transporting land snails safely across the sea". And yet after a careful study of the West Indian molluscan fauna he rejects the theory that the Antilles could have been populated by forfuitous means of conveyance. "The fact", he says, "that the operculates form so large a proportion of the Antillean landsnail fauna, that a majority of the genera are found on two or more of the islands and the mainland, while nearly every species is absolutely restricted to a single island, appears to me to be very strong testimony in favour of a former general land connection." More definite information as to the age of some of the Antillean faunistic elements has been supplied by Dr. Pilsbry (40). In speaking of the Helicidae, a large family of land snails, he informs us that the West Indies claim one group of genera, Sagda, Thysanophora and Zaphysema of evidently great age and unknown ultimate affinities, but that the other elements Pleurodonte, Cepolis and Polymita are Mesozoic or early Eocene immigrants from the mainland and primarily from Asia. As for the Urocoptidae he believes that their first radiation may have occurred on a Mesozoic Antillean land area.

One of the most valuable zoological testimonies as to the geological age of the West Indies is furnished by the presence there of that archaic arthropod Peripatus. These delicate creatures are nocturnal and spend the day under stones and fallen timber. As exposure to sunlight or salt water is quickly fatal to them, they are not liable to accidental conveyance across the sea. And indeed most authorities are of opinion that their presence on an island can only be explained by assuming a 
former land connection with some mainland. America is now known to be inhabited by the two genera Oroperipatus and Peripatus (14). The former being the more primitive lives on the pacific side of Central and South America whereas the other inhabits Eastern South America, Central America and the Antilles. Four well-marked groups or subgenera of Peripatus have been recognized. One of these is peculiar to Jamaica, a second occurs in Venezuela, Colombia, Panama, Costa Rica, Jamaica, Haiti, Porto Rico and on the Lesser Antilles from St. Thomas to St. Vincent. Another has been observed in Eastern South America and Trinidad. A fourth has extended its range from the Southern Continent to Trinidad, Tobago and Grenada. It seems as if the latter three islands were joined to the mainland of South America at a time when the Greater Antilles were connected with other of the Lesser Antilles and with Central America.

Probably the best known group among the remaining invertebrates is that of the butterflies and moths (Lepidoptera). Although it would seem as if these should easily be transported by wind from the mainland, one of the foremost authorities claims even for their present distribution the necessity of great changes in the past disposition of land and water. As the result of his investigations Dr. Pagenstecher (39) concluded that the Antilles had evidently been connected by land with Central and South America, but not with the Northern Continent.

A reference to the many faunistic papers that have been published on certain groups of Antillean invertebrates cannot be attempted. Some of these papers are the results of hurried visits to one or more of the West Indian Islands, others represent more ambitious researches. Scarcely any of them deal with the origin of the fauna of the Antilles as a whole. The only other author who has made a resolute endeavour to solve the problem of the origin of the fauna is Dr. LuTz (30). For that purpose he utilized the distribution of the spiders. He dwells on the well-known fact that young spiders of nearly all families are more or less given to what he calls "ballooning". Considering the exceptional facilities for accidental dispersal of these "ballooning" families, it seems to me that the results of the enquiry would have been more promising if they had been based only on such genera which do not possess those facilities. The idea of former changes in the disposition of land and water does not appeal to Dr. LUTZ, and he prefers the apparently less complex theory that the spider fauna of the Antilles is entirely due to accidental dispersal.

As regards the vertebrates, Dr. BARBour's treatise (11) on the reptiles and amphibians is in many respects one of the most valuable faunistic contributions hitherto published on the Antilles. "The West Indian fauna", he remarks, "is obviously one which has descended from species which formerly ranged over great areas of land which, in connection with each other at various times, as well as with the mainland of Central and South America, have gone to make up the area we may call Antilles." Dr. BARBour demonstrates clearly that flotsam and jetsam dispersal played an insignificant part in the making of the Antillean fauna. If fortuitous distribution of species occurred to any extent the composition of the fauna would be very different from what it actually is. As the result of his herpetological studies Dr. GADOw (22) favours the view that in Miocene times at any rate "Antillea" was joined by land to the Continent. And incidentally it may be noted that the occurrence of a fossil giant tortoise (Testudo cubensis) in Cuba greatly strengthens these opinions. Of all the West Indian vertebrates the birds ought to be the most liable to accidental dispersal, and their distribution all over the Antilles should clearly show their fortuitous origin. Yet Dr. CHAPMAN (13) who made a study of the Antillean Ornithology favours the theory of a former land connection of the West Indian islands with the mainland. Referring in particular to Cuban birds and mammals he believes that many of the species now resident in Central America had not arrived there when Cuba was joined by land to the mainland.

The mammals should be the deciding factor in our enquiries concerning the origin of the West Indian fauna. And indeed, as Mr. LYDEKKER (31) remarked "there seems little doubt from the evidence of the mammals alone, that they (West Indian islands) have been connected with the mainland." Dr. AlLEN's conclusions (2) likewise agree with those of many of the naturalists cited in so far as he considers the continental affinity due to the existence of former land bridges. He lays particular stress on the distribution of bats which he thinks require land bridges for their dispersal just as much as terrestrial mammals do. Bearing upon this view it is interesting to note what Dr. KNUD 
ANDERSEN (4) one of our foremost authorities on bats thinks of their modes of dispersal. His careful studies of the races of the genus Artibeus for example enabled him approximately to trace the dispersal of one group from South America by way of Trinidad, Tobago and Grenada to Guadeloupe, of another from Central America by way of Honduras to Jamaica, Porto Rico to St. Kitts and of a third from Central America by way of Yucatan to Cuba. He assumes the former existence of three complete or nearly complete land connections between the islands and the mainland in order to explain the present distribution of these groups or races of bats.

A large number of biologists and geologists have thus expressed themselves in favonr of the theory that the West Indies were formerly joined to one another by land and to the Continent. But Dr. MATthew has brought forward some reasons for rejecting this opinion in a valuable review of the Antillean recent and fossil mammals (34). The nearest relatives of the insectivores he holds to be certain imperfectly known mammals of very primitive type in the North American Eocene and Oligocene. The rodents he thinks are clearly of South American affinities. As regards the edentates of which five genera lived in the West Indies, he is satisfied that they are derived from the primitive Megalonychidae of the South American Miocene. Concerning the origin of these types or their mode of colonization on the Antilles, the author does not deny that the Greater Antilles may have been united with one another in the late Tertiary as far eastward as the Anquilla Bank. But he contends that the West Indian islands could not have been connected with North America at any time in the Tertiary Era or indeed with either Central or South America. According to his theory the mammals all arrived on the islands on natural rafts and he claims that oversea transportion for birds, bats, amphibians, fishes and invertebrates presents a much simpler problem. The instructive maps on the hypothetical outlines of continents in Tertiary times published by Dr. MATTHEw (32) show that he fully appreciates the vast changes in the distribution of land and water that have taken place in many parts of the globe within comparatively recent geological times. And although geological researches have not proved that similar profound changes have occurred throughout the West Indian area in Tertiary times, strong evidence at any rate to that effect has been submitted not only on geological but on paleontological grounds. When we take into consideration moreover that Dr. MATTHEW admits the probable existence of a very large land surface in the Caribbean Sea which was subsequently submerged to form the Greater Antilles, one cannot help wondering why he should reject a theory which has been so ably supported by many eminent independent workers. Surely his objection that ungulates, carnivores and other mammalian groups ought to occur on the islands if they ever had been connected with the mainland is a weak one.! Ungulates would have lived in the plains of the now submerged land and have perished along with any larger carnivores at the period of subsidence. As the land continued to sink, a tremendous struggle for existence must have taken place which evidently wiped out the greater part of the mammalian fauna. The evidence from the caves indicates that this extinction of the vertebrate fauna still continues. It almost seems as if Dr. MATTHEW had some other reasons for supporting the theory of flotsam and jetsam colonization of the Antilles. And indeed they are to be found in a paper dealing with the subjects of climate and evolution (33). It would be out of place here to discuss this essay or its bearings. Suffice it to remark that the argument or thesis he puts forward in that essay is that land vertebrates in later geological epochs have radiated from Holarctic centres of dispersal and that secular climatic change has been the principal cause of their migrations. Secular climatic changes are supposed to have consisted in alternations of moist and uniform with arid and zonal climates. Hypothetical land bridges connecting continents now separated by deep oceans appear to him improbable and unnecessary for the purpose of explaining problems of geographical distribution. Finally he argues that the known facts point to a general permanence of continental outlines during later geological times. Now since MATTHEW assumes that the Antilles are oceanic islands consequently their fauna must have reached them by accidental causes of dispersal. He thus approaches the whole problem from an entirely new standpoint and his methods are quite at variance with those adopted by biologists. It would be futile therefore to follow him into the unfamiliar arguments it involves. We have been accustomed to proceed from the known causes of the present to the unknown of the past, and this seems a more satisfactory method than the adoption of the reverse principle. Biologists have studied the present causes of dispersal in all climatic zones and have come to the conclusion that 
they progressed in past times on the same lines as they do now. Differences of opinion must always arise especially when we apply the known facts to the formulation of theories as to the changes in the former disposition of land and water that are considered necessary to explain problems of existing distribution. But the views of the many botanists, zoologists, geologists and paleontologists cited agree fairly well as to the Antilles having been connected with one another some time during the Tertiary Era and with portions of the mainland. Those who have incidentally referred to the West Indian problem on general faunistic grounds such as WALlace (50), von Ihering (28), ARLDT (10), and myself (43) all expressed themselves in similar terms.

We can now go further than this and indicate approximately the probable paleogeographical conditions of the West Indian region during the Tertiary Era. An early but probably not the first colonization of the Antillean land surface no doubt took place at the beginning of that era. This land was then connected across Central America with a western prolongation of northern South America. Northward the Antillean land may possibly have been joined to north-eastern North America and eastward to Southern Europe. Although a profound subsidence supervened in later Eocene times which was continued during the Oligocene Period, none of the Greater Antilles and few of the Lesser were entirely covered by water. The remnants of the early Tertiary vertebrates and invertebrates were thus able to persist to the present day. Even during this period of depression more extensive land-surfaces - for example in the Lesser Antilles - may have been preserved, and it is by no means evident that the whole Antillean area subsided to the same degree. Central America had never been a continuous landsurface. It only consisted during that period of depression of a series of large islands. Sometime during the Miocene Period the whole area again rose forming a continuous land mass and permitting immigration of animals and plants from Central and north-western South America. How much of the Caribbean Sea existed at that time is doubtful, but it seems likely that one or more straits within the Lesser Antillean region permitted the Atlantic waters to wash the shores of the newly formed Central America. And even in Miocene times or later a marine channel may still have remained joining the waters of the Atlantic and Pacific Oceans possibly across the Isthmus of Tehuantepec. Animals and plants were thus able to invade the Antillean territory from the south by way of Trinidad, which was then joined to the neighbouring continent and from the western land connections which no doubt reached the lands that lay on the Pacific side of Central America, receiving such remnants of the South American biota still existing there. There are indications that somewhat similar conditions persisted until the early part of the Pliocene Period. After that Central and South America as well as the Antilles gradually assumed their present state.

\section{BIBLIOGRAPHY.}

\section{LIST OF WORKS CONSULTED IN THE PREPARATION OF THIS PAPER.}

1. Agassiz, A. On the dredging operations carried out by U. S. Steamer Blake. - Bull. Mus. Comp. Zoology; Harvard, Vol. V. 1879.

2. Allen, G. M. Mammals of the West Indies. - Bull. Mus. Comp. Zoology; Harvard, Vol. LIV, 1911.

3. Allen, J. A. $\Lambda$ n extinct Octodont from the island of Porto Rico, West Indies. - Ann. New York Acad. Sc. Vol. XXVII. 1916.

4. ANDeRsen, KNUd. A monograph of the Chiropteran genera Uroderma, Enchisthenes and Artibeus. - Proc. Zoological Society, London, 1908.

5. Anthony, H. E. Preliminary report of fossil mammals from Porto Rico. - Annals New York Acad. Sc. Vol. XXVII. 1916.

6. - - New fossil rodents from Porto Rico. - Bull. Amer. Mus. Nat. Hist. Vol. XXXVII. 1917.

7. - - Indigenous mammals of Porto Rico, living and extinct. - Memoirs Amer. Mus. Nat. Hist. (N. S.) Vol. II. 1918.

8. - Mammals collected in Eastern Cuba. - Bull. Amer. Mus. Nat. Hist. Vol. XLI. 1919.

9. —- New mammals from Jamaica. - Bull. Amer. Mus. Nat. Hist. Vol. XLII. 1920. 
10. ARLDt, Th. Die Entwicklung der Kontinente und ihrer Lebewelt. - Leipzig, 1907.

11. BARBOUR, Тн. A contribution to the zoogeography of the West Indies, with special reference to amphibians and reptiles. - Memoirs Mus. Comp. Zoology; Harvard, Vol. XLIV. 1914.

12. Brown, A. P. \& H. A. PILsBry. Freshwater Mollusks of the Oligocene of Antigua. - Próc. Acad. Nat. Sc. Philadelphia. Vol. LXVI. 1914.

13. Chapman T. M. Notes on birds and mammals near Trinidad, Cuba, with remarks on the origin of the West Indian bird life. - Bull. Amer. Mus. Nat. Hist. Vol. IV. 1892.

14. Clark, Austin H. The present distribution of the Onychophora, a group of terrestrial invertebrates. - Smiths. Miscell. Coll. Vol. LXV. 1915.

15. COPE, E. D. Exhibition of the bones and teeth of a large rodent from a cave on the island of Anquilla. - Proc. Academy Nat. Sc. Philadelphia, 1868.

16. - - Descriptions of two large extinct rodents from Anquilla, West Indies \&c. - Proc. Acad. Nat. Sc. Philadelphia, Vol. XI. 1871

17. De CASTRo, M. F. De la existencia de grandes mammiferos fosiles en la isla de Cuba. - Revista Minera Vol. XVI. 1865.

18. EgGers, H. F. A. The flora of St. Croix and the Virgin islands. - Bull. U. S. Nat. Mus. Washington, 1879.

19. Eigenmann, C. H. Freshwater fishes of Western Cuba. - Bull. U. S. Fish Commission Vol. 22. 1902.

20. ENGLER, A. Versuch einer Entwicklungsgeschichte der Extratropischen Florengebiete der südlichen Hemisphaere. Leipzig 1882.

21. FRAZER, PERSIFor. History of the Caribbean islands from a petrographic point of view. - Proc. Acad. Nat. Sc. Philadelphia, Vol. LV. 1903.

22. GADOW H. The distribution of Mexican amphibians and reptiles. - Proc. Zoological Soc. London, 1905.

23. GREGORY, J. W. Contribution to the paleontology and physical geology of the West Indies. - Quart. Journal Geol. Soc. Vol. LI. 1895

24. GuPPY, H. B. Observations of a naturalist in the Pacific between 1886 and 1899, 2 vols. - London 1903-1906.

25. GuPPY, R. I. L. Notes on West Indian geology with remarks on the existence of an Atlantis in the early Tertiary period \&c. - Geological Magazine, London 1867.

26. - - The geological connexions of the Caribbean region. - Transactions Canadian Naturalist. Vol. VIII. 1909.

27. HILL, R. T. The geology and physical geography of Jamaica-study of a type of Antillean development. - Bull. Mus. Comp. Zoology; Harvard, Vol. XXXIV. 1899.

28. IHERING, H. voN. Die Unwandlungen des amerik. Kontinentes während der Tertiärzeit. - Neues Jahrbuch für Mineral. Geol. and Pal. Vol. XXXII. 1911.

29. Johnson, C. W. A revised list of the Diptera of Jamaica. - Bull. Amer. Mus. Nat. Hist. Vol. XLI. 1919.

30. Lutz, F. E. List of the Greater Antillean Spiders, with notes on their distribution. - Ann. New York Acad. Sc. Vol. XXVI. 1915

31. LYDEKKER, R. A geographical history of Mammals; Cambridge, 1896.

32. Matthew, W. D. Hypothetical outlines of the Continents in Tertiary times. - Bull. Amer. Mus. Nat. Hist. Vol. XXII. 1906.

33. - - Climate and Evolution. - Annals New York Acad. Sc. Vol. XXIV. 1915.

34. - - Affinities and Origin of the Antillean Mammals. - Bull. Geological Soc. America Vol. XXIX. 1918.

35. Miller, GerRit, S. Bones of Mammals from Indian sites in Cuba and Santo Domingo. - Smithsonian Miscell. Coll. Vol. LXVI. 1916.

36. - - The teeth of a monkey found in Cuba. - Smithsonian Miscell. Coll. Vol. LXVI. 1916.

37. ORTMANn, A. E. The geographical distribution of freshwater Decapods and its bearing upon ancient geography. Proc. Amer. Philos. Soc. Vol. XLI. 1902

38. - The mutual affinities of the species of the genus Cambarus and their dispersal over the United States. Proc. Amer. Phil. Soc. Vol. XLIV. 1905

39. Pagenstecher, A. Die Lepidopteren-fauna der Antillen. - Jahrb. Nassau. Verein. Nat. Jahrg. LX. 1907.

40. PILsBry, H. A. Tryon's Manual of Conchology; Vols. IX \& XVI. 1894.

41. Praeger, R. Ll. On the buoyancy of the seeds of some Britannic plants. - Scient. Proc. R. Dublin. Soc. Vol. XIV. (N.S.) 1913.

42. - - Origin of the Clare Island flora. - Proc. R. Irish Acad. Vol. XXXI. Section I. 1911-1915.

43. SCHARFF, R. F.. Distribution and Origin of life in America. - London, 1911.

44. Simpson. C. J. Distribution of the land and freshwater Molluscs of the West Indian region and their evidence with regard to past changes of land and sea. - Proc. U. S. Nat. Mus. Vol. XVII. 1894.

45. SPENCER, J. W. Reconstruction of the Antillean Continent. - Bull. Geol. Soc. America. Vol. VI. 1895

46. SuEss, E. Das Antlitz der Erde. - 3 Vols. Wien. 1892-1909.

47. Vaughan, T. W. A contribution to the geol. history of the Floridean plateau. - Carnegie Inst. Washington. Publ. 133. 1910.

48. - - Fossil corals from Central America, Cuba and Porto Rico \&c. - Bull. Smithsonian Inst. 103. 1919.

49. - - The biologic character and geol. correlation of the sedim. formations of Panama in their relation to the geol. hist. of C. America and the West Indies. - Bull. Smithsonian Institution 103. 1919.

50. WALLACE, A. R. The geographical distribution of animals. - London, 2 vols. 1876 